\title{
O ESTADO CONTEMPORÂNEO SOB AS LANTERNAS DE LENIN: DEFINHANDO O GRANDE
} LEVIATÃ

\author{
EL ESTADO CONTEMPORÁNEO BAJO LAS LINTERNA DE LENIN: DESINTEGRANDO EL \\ GRAN LEVIATÁN
}

\section{THE CONTEMPORARY STATE UNDER THE LENIN'S FLASHLIGHTS: LANGUISHING THE GREAT LEVIATHAN}

DOI: http:/ /dx.doi.org/10.9771/gmed.v12i2.37662

Mariléia Maria da Silva ${ }^{1}$

Luciana Pedrosa Marcassa ${ }^{2}$

Resumo: Este texto busca desenvolver uma reflexão sobre a contribuição de Lenin sobre o Estado burguês contemporâneo, considerando suas elaborações teóricas, bem como sua prática política revolucionária. Para tanto, parte da apresentação e análise da concepção liberal de Estado, com base na crítica demolidora do Estado burguês desenvolvida por Marx e Engels, cujos fundamentos foram tão bem absorvidos por Lenin. Finalmente, discute alguns elementos da compreensão de Lenin sobre a edificação do Estado operário, cujo processo erige-se juntamente ao definhamento do próprio Estado.

Palavras-chave: Lenin. Estado. Liberalismo. Marxismo. Revolução.

Resumen: Este texto busca desarrollar una reflexión sobre la contribución de Lenin al Estado burgués contemporáneo, considerando sus elaboraciones teóricas, así como su práctica política revolucionaria. Con este fin, parte de la presentación y análisis de la concepción liberal del Estado, basada en las devastadoras críticas al estado burgués desarrolladas por Marx y Engels, cuyos fundamentos fueron tan bien absorbidos por Lenin. Finalmente, analiza algunos elementos de la comprensión de Lenin sobre la construcción del estado obrero, cuyo proceso se constituye al mismo tiempo que la desintegración del propio estado.

Palabras-clave: Lenin. Estado. Liberalismo. Marxismo. Revolución.

Abstract: This text seeks to develop a reflection on Lenin's contribution about the contemporary bourgeois state, considering his theoretical elaborations, as well as his revolutionary political practice. To this end, it from the presentation and analysis of the liberal conception of state based on the demolishing critique of the bourgeois state developed by Marx and Engels, whose foundations were so well absorbed by Lenin. Finally, it discusses some elements of Lenin's understanding about the building of the workers' state, whose process set itself up along with the languishing of the state.

Keywords: Lenin. State. Liberalism. Marxism. Revolution.

\section{Introdução}

A figura do "Estado" sempre está na berlinda, seja qual for a concepção que lhe acompanha. Do ponto de vista de seus detratores, trata-se de um grande mal a ser expurgado, embora reconheçam, com uma boa dose de desfaçatez, que, sem ele, o abismo se torna evidente. Do ponto de vista de seus defensores mais entusiastas, o Estado, se ocupado por mentes benfeitoras, seria capaz de resolver grande parte dos problemas sociais. Tais posições, aparentemente antagônicas, orientam-se por uma matriz 
comum que naturaliza o Estado como um ente acima das nossas cabeças, revelando-se como uma rica herança civilizatória a ser continuamente aperfeiçoada. O presente artigo tem como propósito apresentar alguns elementos para pensar o Estado burguês contemporâneo, tomando como referência as contribuições de Lenin (1870-1924), especialmente em sua obra O Estado e a revolução, publicada em 1917. Interessa-nos evidenciar a contraposição da concepção de Estado entre os liberais e a perspectiva marxista, dando ênfase às elaborações de Lenin a partir das experiências revolucionárias de 1917, privilegiando o debate que este empreende sobre o Estado, na transição socialista. Ademais, considera-se que o movimento de permanente contato com os clássicos favorece o caminho da reflexão de nossos crônicos e dos sempre mais agudos problemas da existência humana sob a lógica da relação capital trabalho.

Não há dúvida que Vladimir Ilitch Ulyanov, o Lenin, nascido em Simbirsk, na Rússia, em 10 de abril de 1870, em uma família com cinco irmãos, estes também dedicados às lutas revolucionárias contra a autocracia czarista, foi um dos maiores expoentes revolucionários do século XX, cujo legado teórico e político influenciou as revoluções desse período. Seu pai era inspetor escolar, e sua mãe oriunda da pequena burguesia rural. Desde cedo, ainda na universidade de Kazan, dedicou-se às atividades revolucionárias, o que lhe rendeu sua expulsão. Já na Universidade de São Petersburgo conclui o curso de advocacia em 1892, tendo grande destaque acadêmico. Participou de diversos círculos revolucionários, empreendendo críticas aos seus dirigentes, apoiando-se fortemente nos estudos das obras de Marx e Engels. Neste período, advoga em favor de trabalhadores e redige panfletos e textos como subsídio aos movimentos grevistas. É preso em abril de 1895 e condenado em 1897 ao degredo na Sibéria oriental em razão de suas atividades políticas. Casa-se com Nadezhda Konstantinovna Krupskaya (1869-1939) em 1898.

Há consenso entre estudiosos lenineanos, portanto conhecedores de suas obras teóricas e ações políticas, que Lenin não pode ser visto dicotomicamente como um revolucionário que produziu teoria ou um empirista preocupado com as ações práticas. Compreender Lenin e todo o seu arcabouço teórico/prático significa tomá-lo como um revolucionário da práxis que, nas palavras de Deo, Mazzeo e Del Roio (2015, p.8), “articula umbilicalmente ação e reflexão sobre a realidade concreta”. A propósito, é essa característica que faz de Lenin o fundador e organizador do chamado partido de Novo-tipo em contraposição àquela visão tradicional direcionada para uma atuação institucional e parlamentar.

A originalidade estaria, segundo os autores, na concepção de uma organização revolucionária que tem como pressuposto a formação intelectual de seus militantes com o fim de alçá-los à condição de intelectuais de sua própria classe. Consideram, inclusive, que este elemento foi central para que Gramsci aprofundasse o seu conceito de partido. Certamente por isso e por outras contribuições, Lenin é tido por Gramsci como o mais relevante filósofo da práxis dos primórdios do século XX (DEL ROIO, 2018).

O presente artigo está estruturado em três partes. Na primeira, retomamos alguns princípios gerais da concepção liberal de Estado, na linha de seus mais reconhecidos teóricos, tendo em vista explicitar os fundamentos de uma concepção de mundo que, embora ainda não superada na prática, fora abatida pela 
crítica empreendida pela concepção marxista. $\mathrm{Na}$ segunda parte, buscamos apresentar os elementos que permitiram a Marx e Engels desmontar o constructo ideológico e ilusório do Estado liberal, evidenciando suas limitações e insuficiências, tanto para a apreensão dos determinantes do Estado, como para a construção de outra forma de organização social. Finalmente, avançamos sobre as interpretações de Lenin acerca do Estado a fim de indicar suas contribuições para pensarmos o Estado contemporâneo.

\section{A concepção liberal de Estado}

O liberalismo nasce na Modernidade colado à emergência da burguesia como classe social. É uma visão de mundo concebida a partir das transformações econômicas, da mudança na relação da propriedade privada e das progressivas modificações técnicas que levaram ao desenvolvimento das cidades e ao florescimento cultural, intelectual e do comércio. Durante os séculos XVII e XVIII, com o desenvolvimento da filosofia política e das ideias sobre sociedade civil e Estado, importantes autores colocaram-se o problema da autoridade, em particular do governo, levando em consideração sua dupla finalidade, a temporal e a espiritual.

O jurista e diplomata Samuel Pufendorf (1632-1694) ${ }^{3}$ foi quem inaugurou a reflexão sobre o direito natural. Seu pensamento comporta uma singular dualidade que, em alguma medida, reaparece na reflexão dos demais filósofos deste período. De um lado, a exigência de racionalidade na reflexão sobre a lei natural, o direito positivo, o direito das gentes e a constituição da sociedade civil. De outro, a justificativa do poder absoluto, que une o pater famílias ao soberano politico (Estado), ambos investidos de autoridade divina. Segundo seu raciocínio, tem-se que a liberdade e a igualdade entre os homens decorrem da natureza, ou seja, constituem um direito natural, e as relações com o soberano seriam estabelecidas em função do consentimento dos sujeitos, e não mais de uma hierarquia celeste.

Para Pufendorf, a sociabilidade fundada no direito natural tem função política nos Estados e cultural no conjunto das relações humanas (HELL, 1989). Todavia, se os homens são livres e iguais por natureza, mas se associam uns aos outros tendo em vista o cultivo e a conservação de si mesmo, o Estado só pode ser a consagração de outra dualidade, a dualidade do ser humano como homem e como cidadão. Os fundamentos do pensamento político de Pufendorf foram expostos em seu famoso texto Os Deveres do homem e do cidadão, cujas ideias centrais influenciaram diretamente a "Declaração dos direitos do homem e do cidadão" de 1789. A partir daí, o direito natural e o fundamento racional das sociedades humanas, somados à ideia de corpo político, Estado e civilização passaram a compor a teia de novos significados correspondentes às relações entre Estado, sociedade, cultura e educação.

Thomas Hobbes (1588-1679), que era cristão e, como Pufendorf, favorável aos Estados absolutistas, é um dos autores que retoma a dualidade dos poderes explicitada em Pufendorf, buscando, junto à natureza do homem, explicações racionais para justificar que o governo (ou soberano) não provém de Deus, mas de um pacto social entre os cidadãos, quando estes abdicam do seu direito natural para viverem em sociedade. Em O Leviatã, publicado em 1681, o autor explica que, pela natureza, todos os homens são livres e iguais quanto à capacidade de cada um, e também quanto à possibilidade de atingir os fins a Germinal: Marxismo e Educação em Debate, Salvador, v.12, n.2, p. 205-221, out. 2020. $\quad$ ISSN: 2175-5604 207 
que se determinam. Mas como a natureza humana é egoísta, ambiciosa, injusta e brutal, os homens são naturalmente inimigos. Assim, no estado de natureza, impera a guerra de todos contra todos, onde há perigo constante de morte violenta, colocando em risco a paz e a prosperidade dos homens, restando, neste estado, apenas a conservação da vida, do lucro e da reputação.

Nota-se que o princípio da igualdade, uma das características historicamente incorporadas às doutrinas liberais do Estado e da sociedade, não é definido pela função política ou pela filiação divina universalmente conferida a cada indivíduo (tal como nas concepções teológicas da Igreja durante o feudalismo). A igualdade que se inaugura neste momento corresponde à natureza humana, isto é, está vinculada à relação entre os homens naquilo que define as suas capacidades, seu poder de agir e de se apropriar do que necessitam para viver. Assim, já em Hobbes ([1681] 2004) é possível visualizar como a noção de igualdade se articula à posse e à propriedade de cada um, sendo esta a medida e o grau definidores do lugar que os indivíduos ocupam na coletividade. Ademais, a igualdade na sociedade civil vinha acompanhada da noção de liberdade individual, até então inexistente nas formações sociais anteriores.

Por sua vez, a expressão liberdade, para Hobbes ([1681] 2004), tem o significado de ausência de impedimentos externos, de modo que a liberdade, como a igualdade, é um direito natural que cada indivíduo possui de "usar seu próprio poder, da maneira que quiser, para a preservação de sua própria natureza, ou seja, de sua vida" (p.101). Uma vez que essa liberdade não tem qualquer limite a não ser o julgamento e a razão que os indivíduos indicam como adequados para tal fim, a realização dessa liberdade tende à guerra e à morte. Portanto, a fim de evitar o estado de guerra e garantir as condições para uma vida confortável, os homens seriam levados a estabelecer um acordo de transferência mútua de direitos, cujas normas de paz são fundamentadas na razão e no consentimento de todos. O nome que Hobbes dá a esse acordo é pacto ou convenção que, em sua visão, é muitas vezes estabelecido com base em palavras soltas, o que não seria suficiente para definir uma obrigação e impor o seu cumprimento. De acordo com o autor, sem um poder coercitivo que faça refrear a ambição, a avareza e a cólera, não há pacto, já que "os pactos, sem a força, não passam de palavras sem substância para dar qualquer segurança a ninguém” (HOBBES, [1681] 2004, p.127). Eis a essência do Estado na filosofia de Hobbes, isto é, um poder coercitivo, soberano e absoluto, cujo papel é limitar a liberdade individual, tanto para evitar a violência e a guerra, como para favorecer a prosperidade e conformar coletivamente a vontade.

Diferentemente de Hobbes, na filosofia de Locke (1632-1704) o Estado assume funções especificamente comprometidas com o bom funcionamento da sociedade burguesa, distintas das funções da Igreja e das questões religiosas, que se restringem ao domínio do privado e da ação individual. Filósofo inglês, John Locke era filho de burgueses comerciantes, personalidade importante no quadro político e intelectual da Inglaterra setecentista. Foi um grande defensor da tolerância e da convivência harmoniosa entre Estado, Igreja e entre diferentes religiões.

$\mathrm{Na}$ esteira de suas argumentações acerca da inexistência de ideias e princípios especulativos inatos, Locke procura demonstrar a inexistência de princípios práticos inatos, (dos quais a tolerância religiosa é 
um exemplo), o que lhe permite elaborar uma teoria política sobre a sociedade civil fundada no consentimento comum. Tal como Hobbes, Locke compreende o estado de natureza como "um estado de perfeita liberdade para regular suas ações e dispor de suas posses e pessoas do modo como julgarem acertado" (LOCKE, 2005, p.382).

Ocorre que, conforme argumenta o autor, no estado de natureza, os homens agem individualmente, de acordo com suas conveniências, configurando-se como um estado de barbárie, quase animal, em que o homem está constantemente exposto à violação dos outros, que igualmente possuem as mesmas forças e os mesmos meios. Para Locke, o governo civil é a solução para evitar as inconveniências do estado de natureza. Para edificá-lo, os homens necessitam estabelecer determinadas convenções sociais, deixando de agir como indivíduos para se tornarem membros da sociedade política, empenhando sua força natural no poder executivo do governo, que se torna a medida e o controle dos associados.

Como em Hobbes, para Locke a liberdade é limitada pelo pacto social, mas sua jurisdição não é efetuada pela força e "poder da espada", mas pelo poder das leis. Locke enfatiza que a sociedade política é formada na medida em que os homens deixam sua condição de isolamento e buscam a comunhão em função de interesses comuns, privados, para preservar sua vida, sua liberdade e seus bens. Para este autor, são por razões práticas e úteis que os homens se unem em sociedade e abandonam o estado de natureza. A chamada sociedade política é, portanto, ao contrário do estado de natureza, resultado de um pacto social estabelecido pelo consenso, em que os homens abdicam de seus direitos naturais em nome da constituição e manutenção de uma determinada ordem social.

$\mathrm{Na}$ sociedade civil ou política é a razão, o bom senso e o consentimento de homens que agem livremente na escolha de seus governantes e formas de governo que garantem as condições de liberdade e igualdade dentro da comunidade. Consequentemente, na visão de Locke, o Estado, ou governo, é resultado do consentimento da maioria, definição esta que se apoia numa ética pragmática, utilitária e individualista que tem como objetivo conservar a propriedade, sendo esta o pressuposto do bem público e condição de prosperidade na sociedade civil.

Nesta mesma linha, Jean-Jacques Rousseau (1712-1778) foi quem se preocupou com a necessidade de organizar as forças dadas e apresentar um dispositivo de controle sobre as recém-criadas instituições políticas. Seu enfoque concentra-se sobre as formas de governo, sua relação com o pacto social, a vontade geral e a determinação dos meios para supri-las. Nas reflexões de Rousseau, seguindo a tradição da filosofia política moderna, o homem nasce livre e essa liberdade que é comum e igualmente concedida a todos é consequência da natureza do homem. Porém, como nenhum homem tem autoridade natural sobre seus semelhantes, e sua força não gera nenhum direito, restam as convenções como base de toda autoridade legítima entre os homens. Como Pufendorf, Rousseau pensa que a ordem social dada pelas convenções é produto da cultura, pois os costumes de cada povo conferem especificidades à vontade geral particular de cada Estado. Além disso, a formação de um povo não deriva da simples associação dos homens, ela responde a uma ação moral, que transforma esse conjunto num corpo político, mediante uma deliberação pública consciente que a todos compromete com suas decisões e objetivos. 
Para Rousseau (1995), o legítimo fundamento da sociedade civil, portanto, é a convenção, o pacto, ou mais precisamente o contrato social. Tendo em vista resolver o problema das forças e resistências individuais existentes no estado de natureza e que impedem a conservação desse estado, o contrato é forma de agregar e dirigir essas forças, tendo em vista o interesse comum. Diferentemente de Hobbes, Rousseau não entende que os homens sejam naturalmente inimigos ${ }^{4}$; é a inconstância da propriedade e a relação entre as coisas que gera a guerra. Daí a necessidade de regular a posse, a autoridade, o direito e os deveres através de leis, estabelecidas a partir do pacto original.

O contrato é uma forma de associação que defende e protege a pessoa e seus bens de toda a força comum, para cuja existência deve haver total alienação, por parte de cada associado, de seus direitos naturais a toda comunidade, condições igualmente impostas a todos. Esta associação é direta e cada um é seu próprio juiz. O pacto social, entretanto, não se submete a vontade de alguém em particular, mas sim à vontade geral que, por sua vez, não é a da maioria, mas àquela comum a todos. O governo ou governante que dessas convenções deriva deve pautar-se na lei, estabelecida a partir da vontade geral, que tende ao bem público.

Dessa forma, observa-se que o objetivo da associação política é a conservação, o desenvolvimento e a prosperidade de seus membros, no seio da qual os cidadãos vivem e se multiplicam segundo a direção da vontade geral. E para que essa vontade prevaleça, não pode haver sociedades parciais no Estado. "Só há um contrato no Estado, o de associação, e este exclui qualquer outro" (ROUSSEAU, 1995, p.152). Por isso, só se deve mudar o Governo estabelecido quando ele se torna incompatível com o bem público. Nesse processo, a vontade geral se emudece, mas ela não está anulada, apenas subordinada a outras que a sobrepõem.

Assim, os contratantes tornam-se depositários do bem público, tendo seus direitos respeitados por todos os membros do Estado, já que tais direitos são instituídos por meio de leis expressas do consentimento público. O direito que cada particular tem sobre seu próprio bem está subordinado ao direito que a comunidade tem sobre todos. A liberdade, a igualdade, o direito de propriedade e de participação na gestão do Governo formalizam-se na esfera do Estado, criado e sustentado pelo contrato.

O Estado moderno na concepção liberal é, então, a institucionalização da autoridade política que tem a função de regulamentar os direitos naturais (liberdade e a propriedade), conceder direitos civis e políticos e assegurar o pacto social. O Estado fundado no contrato social é o palco em que são confrontados e dirimidos os conflitos, e onde não restaria espaço para os interesses privados, pois nele deve reinar a vontade geral. Nesse Estado, o governo tem uma função executiva, e pelo poder e força que lhe são conferidos, deve agir em nome das leis estabelecidas pelo consenso geral a fim de garantir a ordem constituída pelo contrato.

Como sabemos, a concepção liberal de Estado representa o nascimento da sociedade burguesa e o desenvolvimento do capitalismo comercial e industrial, com a reorganização da luta de classes e o surgimento de novas forças sociais e produtivas na cena político-econômica. Longe de suprimir a oposição de classes num reino de consensos e acordos bem sucedidos (mas que na verdade tem como 
fundamento garantir a liberdade de mercado e a propriedade privada), o Estado burguês é expressão da concentração da luta, dos conflitos e da dominação de classes entre dois grupos fundamentais: a burguesia e o proletariado. E se o poder material da sociedade está concentrado nas mãos da burguesia, esta se torna a classe dominante, cujos interesses, ao penetrarem a esfera do Estado, confundem-se com a vontade geral. Em seu balanço do Estado moderno no século XIX, Marx e Engels (2001) julgaram com precisão que o "governo moderno é tão somente um comitê que administra os negócios de toda a classe burguesa" (p.27). Eis a crítica que vamos explicitar na próxima parte deste texto.

\section{A crítica e o legado de Marx e Engels sobre a questão do Estado}

No Manifesto do Partido Comunista, de 1848, Marx e Engels (2001) já tinham afirmado que, ao revolucionar os instrumentos, as relações de produção e, consequentemente, as relações sociais em seu conjunto, a burguesia impelia todas as nações para a torrente da civilização, fazendo-as adotarem o modo de produção capitalista, em cuja estrutura ela controlaria os meios de produção, a dispersão da propriedade e da população. Assim, ao aglomerar a população nas cidades, centralizar os meios de produção e concentrar a propriedade em suas próprias mãos, a burguesia obtinha, em consequência, a centralização política.

Ao reunirem os interesses dispersos das diferentes nações em um só interesse de classe, a burguesia passou a interferir na política econômica do capitalismo mundial. Com o desenvolvimento das teorias sobre a economia política inglesa, de David Ricardo e Adam Smith, a burguesia constrói seu império sob o primado da livre concorrência e do Estado de Direito (liberal, contratualista), consolidando uma ética utilitária, mercantil e concorrencial, na qual a sociedade civil é o mercado e o Estado é o mediador dos conflitos e contradições sociais, regulador das crises de superprodução, pacificador dos antagonismos entre as forças produtivas e as relações de produção. Contudo, passados os anseios revolucionários de 1789, a burguesia torna-se conservadora. E para manter-se como classe dominante, ela é obrigada a criar conceitos, ideias, laços, enfim, manifestações ideais capazes de ocultar as contradições entre capital e trabalho geradas pelo desenvolvimento do capitalismo.

$\mathrm{Na}$ Ideologia alemã, Marx e Engels advertem para o fato de que cada nova classe no poder, para alcançar seus fins, é obrigada a representar seu interesse particular como sendo comum a todos os membros da sociedade, dando um caráter universal aos seus pensamentos, isto é, tornando universal aquilo que é particular de uma classe. Afirmam ainda que, com a divisão capitalista do trabalho, a atividade material e intelectual, o gozo e o trabalho, a produção e o consumo, cabem a indivíduos distintos. Então, a possibilidade de que esses elementos não entrem em conflito implica unicamente a hipótese de acabar com a divisão do trabalho. Daí que interessam as expressões mentais, as representações aparentes do indivíduo isolado, uma vez que diluem e encobrem as contradições entre o interesse do indivíduo singular e os interesses coletivos em um único interesse "universal", fazendo nelas subsumir os conflitos que nascem e se reproduzem no modo de produção da vida e nos mecanismos de troca, circulação e consumo de mercadorias. 
O maior expoente dessa concepção pós-revolucionária de Estado, embora heterodoxo à tradição liberal e contratualista, é Hegel. No momento em que a burguesia hegemônica está preocupada com os limites e possibilidades do utilitarismo, com a expansão ilimitada dos direitos individuais e com a força do mercado e da sociedade civil, Hegel cumpre uma importante função ideológica que, de acordo com Boron (2003), mesmo não sendo um representante fiel dos Estados capitalistas, acaba preenchendo uma lacuna que os contratualistas tinham deixado em aberto: a de apresentar o Estado burguês como esfera superior da ética e da razão, como arena em que se desenvolvem as contradições da sociedade civil. Para o mesmo autor, trata-se de um Estado "cuja 'neutralidade' na luta de classes se materializa na figura de uma burocracia onisciente e isolada dos sórdidos interesses materiais em conflito, o que lhe faculta aparecer como o representante dos interesses universais da sociedade e como a encarnação de uma juridicidade despojada de toda a contaminação classista” (BORON, 2003, p.73)

Marx (1993), em sua Contribuição à crítica da Filosofia do Direito de Hegel, observou que "a filosofia alemã do direito e do Estado é a única história alemã que está al pari com a época moderna oficial” (p.84). Para ele, Hegel é a expressão da mais profunda e completa da filosofia alemã do direito e do Estado, cuja elaboração "surge ao mesmo tempo como análise crítica do Estado moderno e da realidade a ele associada e como a negação definitiva de todas as anteriores formas de consciência na jurisprudência e na política alemã" (MARX, 1993, p.85). Entretanto, Marx lembra que na Alemanha as condições reais de realização desta política (o que para outras nações constituía uma ocupação prática) não estavam postas, de modo que a filosofia alemã do Estado e do direito não passa de um corte crítico com sua própria reflexão filosófica. E reafirma:

Só a Alemanha poderia produzir a filosofia especulativa do direito - este pensamento extravagante e abstrato acerca do Estado moderno, cuja realidade permanece no além (mesmo se este além fica apenas do outro lado do Reno) - o representante alemão do Estado moderno, pelo contrário, que não toma em linha de conta o homem real, só foi possível porque e na medida em que o próprio Estado moderno não atribui importância ao homem real ou unicamente satisfaz o homem total de maneira ilusória. Em política, os alemães pensaram o que as outras nações fizeram. A Alemanha foi a sua consciência teórica (MARX, 1993, p.85).

Como se sabe, para Marx e Engels, Hegel desenvolve uma visão invertida da realidade. Para este último, a história é realização da Ideia e se move segundo a liberdade individual de cada um, culminando na sociedade burguesa, onde, não por acaso, todos seriam livres. Quanto ao Estado, este aparece como a esfera da racionalidade e da eticidade e, juntamente com as superestruturas políticas, constituem os sujeitos sociais da vida real, enquanto que a sociedade civil, lócus em que se movem os indivíduos concretos e onde se localiza a esfera do trabalho (corporações) e da família, figura apenas como um momento particular da vida estatal. Marx, então, desconstrói a dialética hegeliana, demonstrando que é a própria sociedade capitalista que gera imagens invertidas sobre si mesma, uma vez que repousa no caráter alienado do processo produtivo, na abstração do Estado democrático e no fetiche da mercadoria (BORON, 2003).

No conjunto de sua obra, Marx examinou vários tipos de alienação: religiosa, filosófica, política e a econômica. Esta última, porque se dá sobre a atividade fundamental do homem como ser da práxis, o

Germinal: Marxismo e Educação em Debate, Salvador, v.12, n.2, p. 205-221, out. 2020. $\quad$ ISSN: 2175-5604 212


trabalho, é a mais profunda e determinante. No terreno da política, a alienação se expressa no Estado burguês, na medida em que este pressupõe uma vida dupla: a universalidade do Estado e a particularidade do indivíduo, o interesse geral e o interesse privado, a comunidade política e a sociedade civil, conflito este que se estabelece entre o indivíduo vivo e o cidadão. Em A questão judaica, Marx verifica que, no Estado, o indivíduo (burguês) tem uma vida de aparência e participa da vida política de modo sofístico, assim como o cidadão (membro da comunidade) é burguês sofisticamente. Isto significa que:

Onde o Estado político atingiu o pleno desenvolvimento, o homem leva, não só no pensamento, na consciência, mas na realidade, na vida, uma dupla existência - celeste e terrestre. Vive na comunidade política, em cujo seio é considerado ser comunitário, e na sociedade civil, onde age como simples indivíduo privado, tratando os outros homens como meios, degradando-se a si mesmo em puro meio e tornando-se joguete de poderes estranhos (MARX, 1993, p.45).

Em outras palavras, o Estado burguês é a declaração da universalidade abstrata do cidadão e da particularidade concreta do indivíduo privado (burguês), ou seja, da vivência, no plano ideal, de valores como igualdade e justiça, enquanto reina a desigualdade e a injustiça realmente existentes entre os indivíduos. A existência do Estado como totalidade, visto como representante do interesse geral, convive com os pressupostos da vida egoísta, que continuam a existir na sociedade civil, fora da esfera política.

Isto porque, segundo Marx, o Estado tem como pressuposto elementos materiais e espirituais, a propriedade privada, no primeiro caso, a religião e a cultura no segundo. Mas para se constituir como universalidade, como a "vida genérica do homem", o Estado se coloca em oposição à vida material do homem, ou seja, acima dos elementos particulares, das condições em que os homens nascem, vivem, lutam e se reproduzem. A comunidade política se estabelece, pois, sob um conjunto de preceitos abstratos (liberdade, igualdade, segurança, propriedade) como se fossem interesses gerais, numa independência ideal dos elementos particulares da vida civil, onde as distinções reais são consideradas como não-políticas. Dessa forma, na concepção liberal-burguesa, buscava-se solucionar o problema da relação entre sociedade civil e Estado abolindo-se a dimensão política da vida civil, isto é, elevando a política ao reino do Estado ético (como queria Hegel), ou à manifestação da vontade geral (como desejava Rousseau), ou ainda transformando o Estado num mero poder executivo, neutro e justo, regulador dos conflitos e interesses particulares (como indicara Locke). Conquistando a emancipação política da sociedade civil em relação ao Estado, os interesses econômicos, comerciais e mesquinhos eram conservados e assegurados no âmbito da vida privada, enquanto no Estado se desenrolava o teatro da vida social, em sua tentativa de universalizar a ética burguesa, acima dos conflitos de classe, embora reforçando, de fato, os interesses econômicos e privados da burguesia. É dessa maneira que o homem aí é visto como cidadão, mas somente enquanto “membro imaginário de uma soberania imaginária, despojado da sua vida real individual, e dotado de universalidade irreal" (MARX, 1993, p.46).

Observa-se, então, que os chamados direitos do cidadão são os direitos políticos, que só podem ser exercidos quando se é membro da comunidade política. Seu conteúdo é a participação na vida política da comunidade, na vida do Estado. Enquanto que os direitos do homem, distintos dos direitos do cidadão, representam os direitos de um membro particular da sociedade civil, do homem egoísta, do 
homem separado dos outros homens e da própria comunidade. É a liberdade individual que se funda na separação do homem a respeito do homem, como direito do interesse pessoal. Em outras palavras, tratase da liberdade de mercado, que é uma falsa liberdade, uma vez que o trabalhador não tem outra alternativa para sobreviver, se não, vender sua força de trabalho em condições não escolhidas por ele quando então se fundamenta a alienação no processo de produção, ou seja, no trabalho. Em A questão judaica, Marx explica que a aplicação prática do direito do homem à liberdade é o direito à propriedade privada, sendo que "esta liberdade individual e a respectiva aplicação formam a base da sociedade civil. Leva cada homem a ver nos outros homens, não a realização, mas a limitação de sua própria liberdade" (MARX, 1993, p.57)

Portanto, os direitos do homem não vão além do homem egoísta, do burguês, membro da sociedade civil, enquanto indivíduo separado da comunidade. Ao tornar a cidadania uma abstração, o Estado legitima a condição da classe burguesa (posto que a liberdade individual e a liberdade de mercado só à burguesia interessam) e declara o burguês como o "ser autêntico" (também porque só a ele pertence a propriedade privada), impossibilitando a realização do homem, nos direitos do homem, como ser genérico. Ao contrário, a própria vida genérica, isto é, a sociedade, surge como um sistema externo ao indivíduo, como um sistema cujas leis servem, de um lado, para limitar a sua independência original - tal como aparece em Rousseau - e de outro, para garantir que as carências e necessidades "naturais" sejam atendidas, bem como o interesse privado, a preservação da propriedade e de suas posses egoístas - como propõe Locke.

Diante do exposto, fica claro que Marx possui uma concepção negativa da política e do Estado. Enquanto Hobbes via no Estado um poder soberano capaz de colocar fim à "guerra de todos contra todos", instaurando uma paz que permitiria o desenvolvimento da sociedade de classes; ali onde Rousseau, descurando da dominação de classes e das determinações sociais que afetam as condições de vida e de participação de cada indivíduo na sociedade, acreditava fundar uma comunidade democrática com base em um pacto social entre indivíduos livres; e onde Hegel via a realização da ética e da razão, a esfera mesma da universalidade da vida social, Marx viu a política e o Estado como instâncias de alienação, as quais garantiam a manutenção de uma sociedade baseada na exploração do homem pelo homem (BORON, 2003).

Visto como entidade parasitária, manifestação da sociedade de classes, como instituição responsável pela reprodução da dominação de classes e da exploração dos trabalhadores, o Estado seria, então, para Marx e Engels, uma expressão transitória da história humana - ou precisamente sua préhistória. Não poderia ser concebido, senão, como uma etapa que estaria destinada a ser superada na medida em que o proletariado concretizasse a sua missão histórica, que é a instauração da sociedade sem classes. Neste momento, além da extinção do Estado, que é reabsorvido pela sociedade civil, e da instituição do autogoverno dos produtores, realiza-se o fim da política como contrato, haja vista que, "na sociedade comunista se supõe que os fundamentos últimos do conflito político, a apropriação desigual da 
propriedade e da riqueza e a distribuição desigual dos frutos do progresso técnico, terão desaparecido" (BORON, 2003, p.93).

\section{Lenin e o Estado: lanternas para o debate contemporâneo}

Antes de tudo é preciso registrar que, como um grande estudioso da doutrina de Marx, Lenin, obviamente, estava seguro de que a análise do Estado moderno não poderia ser descolada da reprodução do sistema capitalista, da propriedade privada e do antagonismo de classes, ou seja, tinha a clareza de que seria necessário se apropriar de uma teoria crítica capaz de desvelar a sociedade burguesa e construir a superação dessa. Nas palavras de Lukács (2012), “[...] a simples colocação dos problemas que Marx e Engels consideravam questões de sua teoria de Estado significa já o reconhecimento da revolução proletária" (p.77). Essa teoria foi lançada quando Marx, ao apreender a sociedade burguesa para além de sua aparência empírica e imediata, nos revela a lógica do capital (NET'TO, 2011), que somente pode ser compreendida como uma totalidade concreta.

Neste ponto, embora a própria compreensão de Marx sobre o caráter do Estado burguês tenha alcançado sua maturidade na medida em que avançava em seus estudos sobre o capital, o excerto abaixo, retirado do texto A questão judaica, é indicativo do "espírito" com o qual Lenin lê Marx:

A emancipação humana só será plena quando o homem real e individual tiver em si o cidadão abstracto; quando como homem individual, na sua vida empírica, no trabalho e nas suas relações individuais, se tiver tornado um ser genérico; e quando tiver reconhecido e organizado as suas próprias forças (forces propres) como forças sociais, de maneira a nunca mais separar de si esta força social como força política (MARX, 1993, p. 63).

Difícil descrever em poucas linhas a portentosa contribuição de Lenin para resgatar o pensamento de Marx e Engels sobre o Estado e o papel da ditadura do proletariado na revolução socialista, não somente pelo fato de ter promovido com elevado rigor a retomada destes princípios, mas, sobretudo, pela sua capacidade de mantê-los vivos na sua concretude. O esforço de síntese aqui empreendido tem como objetivo trazer alguns elementos da atuação de Lenin e sua experiência na Revolução Russa de 1917, buscando ressaltar a importância deste revolucionário para pensar o Estado moderno e contemporâneo, apoiando-se especialmente na obra O Estado e a revolução, escrito em 1917, na efervescência dos acontecimentos.

Primeiramente ressalta-se a participação ativa e o posicionamento de Lenin nos debates da II Internacional. É amplamente sabido que o seu principal combate era contra o reformismo e o dogmatismo, deturpadores dos fundamentos da doutrina de Marx, com implicações desastrosas para a ação revolucionária - não podemos esquecer que estamos falando de alguém que dedicou sua vida à superação da forma capital. Tal combate, sem tréguas, deve ser examinado mediante a própria condição de Lenin como legatário de uma dada tradição teórico-política e protagonista de um rico momento histórico, no qual foi capaz de não apenas atualizar as concepções de Marx e Engels, mas, principalmente, promover novas análises para situações ainda não vivenciadas, trazidas pelo capitalismo em sua fase imperialista caracterizações certeiramente elencadas por Braz (2015). 
Na análise de Lukács (2012), a questão do Estado não foi suficientemente problematizada pelas tendências dominantes na II Internacional. "Todos, sem exceção, assumiram simplesmente o Estado da sociedade burguesa" (p.78). A crítica, quando comparecia, direcionava-se para o combate às formas externas de atuação do Estado, consideradas desfavoráveis ao proletariado. Em outras palavras, a perspectiva da totalidade da classe proletária não era levada em conta, o que prevalecia era a visão dos interesses particulares imediatos, aponta o autor.

É importante assinalar o regresso de Lenin do exílio na Suíça, em abril de 1917, já com a convicção de que a revolução democrático-burguesa na Rússia estaria finalizada e que o caminho para a revolução socialista estaria posto. Trata-se do momento em que o poder de Estado na Rússia passava agora à classe burguesa, em colaboração com parcela do movimento político da classe operária e também do campesinato, constituindo o governo provisório republicano. Nas palavras de Fernandes (2007, p.7), referindo-se a Lenin “[...] um vulcão desabou sobre a Rússia com a sua chegada, vergando-a sob o peso do marxismo, resgatado em toda a sua pureza como força revolucionária. A primeira versão desse avanço está contida nas teses e na forma mais elaborada que elas tomam na brochura As Tarefas do Proletariado em Nossa Revolução".

Nesse sentido, a questão estratégica se colocava na urgente necessidade de garantir a capacidade de conquista de hegemonia da classe trabalhadora revolucionária nessa dualidade de poder. Assim referese Lenin nas Teses de Abril: "A particularidade do momento atual da Rússia é que o país está passando do primeiro estágio da revolução - que deu o poder à burguesia, pelo fato do proletariado não ter o suficiente nível de consciência e de organização - ao segundo estágio, que deve colocar o poder nas mãos do proletariado e dos setores mais pobres do campesinato". (LENIN, 1977, s/p.).

Diante desse quadro complexo ${ }^{5}$, Lenin, como líder bolchevique e posteriormente como chefe do Estado proletário, definirá uma série de tarefas com o intuito de garantir que a esquerda revolucionária, diante de suas hesitações, não cedesse à pressão de confiar à própria burguesia a incumbência de estabelecer uma democracia que, obviamente, só poderia dar-se no âmbito burguês. Portanto, era crucial estabelecer como metas a tomada do poder proletário, o aniquilamento do Estado burguês e a insurreição armada. Vale registrar que a experiência de 1905 permitiu acúmulos, elevando o nível dos debates e condições objetivas para a luta pela instauração da ditadura democrática do proletariado e dos camponeses. Na análise de Del Roio (2007, p. 71), essa experiência deve-se menos pelo tempo decorrido, tendo em vista o maior desenvolvimento das forças produtivas, e mais pelo "predomínio da situação nacional antes e da situação internacional de guerra imperialista agora, a qual colocava a revolução socialista como tarefa imediata".

No entendimento de Del Roio, dadas essas condições, o processo de instauração da ditadura democrática do proletariado na Rússia significaria somente "[...] um momento de aproximação da revolução socialista internacional, cujo território compreendia toda a área atingida pela guerra imperialista" (p.71), e que esta ditadura do proletariado e do campesinato alcançaria sua concretude quando os sovietes tomassem o poder rumo à constituição do Estado operário e socialista. Portanto, a conquista da 
hegemonia política nos sovietes, por parte dos bolcheviques, trazendo consigo a pequena-burguesia, esta titubeante em relação ao apoio à burguesia, tornou-se crucial.

A orientação de Lenin nas Teses de Abril é cristalina nesse sentido:

Nenhum apoio ao Governo Provisório. Explicar a completa falsidade de suas promessas, sobretudo sobre a da renúncia das anexações. Desmascarar este governo, que é um governo de capitalistas, invés de propagar a inadmissível e ilusória "exigência" de que deixe de ser imperialista.

Reconhecer que, na maior parte dos Sovietes de deputados operários, nosso partido está em minoria e, por agora, em uma ampla minoria, diante do bloco de todos os elementos pequeno-burgueses e oportunistas - submetidos à influência da burguesia, e que levam esta influência ao seio do proletariado. Que compreende desde os Socialistas Populistas e os Socialistas Revolucionários até o Comitê de Organização (Cheidze, Tsereteli, etc) Steklov, etc, etc. (1977, s/p).

Assim sendo, a obra O Estado e a revolução, elaborada em outubro de 1917, no caminhar do processo revolucionário, expressa a premente necessidade de retomar com a máxima precisão e rigor as fundamentais elaborações de Marx e Engels sobre a natureza do Estado, com o intuito de não apenas garantir sua correta apreensão, mas especialmente dar a essas o sentido da práxis. Isto é, como uma ação conscientemente transformadora, guiada pela ciência revolucionária do proletariado.

Não por acaso, no primeiro prefácio à obra, Lenin expõe a arquitetura básica sobre a qual se assenta sua proposta. Em primeiro lugar, como já aludido, está a passagem “[...] em revista [da] doutrina de Marx e Engels sobre o Estado, detendo-nos mais demoradamente nos pontos esquecidos ou desvirtuados pelo oportunismo" (2007, p. 18). Na sequência, dedica-se a estudar as doutrinas desvirtuadas mediante seu representante-mor, Karl Kautski e, por fim, apresenta os ensinamentos das revoluções russas de 1905 e 1917, ressaltando que o relacionamento “[...] entre a revolução socialista do proletariado e o Estado adquire [...] não só uma significação política prática, mas também um caráter de palpitante atualidade, pois fará as massas compreenderem o que devem fazer para se libertarem do jugo capitalista em futuro próximo" (p.19).

Daí a síntese de Fernandes (2007, p.10) ao redigir a apresentação para O Estado e a revolução: trata-se de uma obra com um caráter educativo, posto que era urgente esclarecer, ao máximo, o Estado que precisaria ser "conquistado, transformado e destruído". Ainda assim, não foram poucas as difamações sobre supostas falsificações por parte de Lenin em torno dos textos de Marx e Engels. Acusações infundadas, tendo em vista a rigorosidade e honestidade com que Lenin se apropria dos ensinamentos destes. Não por acaso, a primeira referência direta que comparece no livro é a emblemática síntese de Engels em A origem da família, da propriedade privada e do Estado, de 1894:

O Estado não é pois, de modo algum, um poder que se impôs à sociedade de fora para dentro; tampouco é a 'realização da ideia moral', nem 'a imagem e a realidade da razão' como afirma Hegel. É antes um produto da sociedade, quando esta chega a um determinado grau de desenvolvimento; é a confissão de que essa sociedade se enredou numa irremediável contradição com ela própria e está dividida por antagonismos irreconciliáveis que não consegue conjurar. Mas para que esses antagonismos, essas classes com interesses antagônicos colidentes não se devorem e não consumam a sociedade numa luta estéril, faz-se necessário um poder colocado aparentemente por cima da sociedade, chamado a amortecer o choque e a mantê-lo dentro dos limites da 
"ordem". Este poder, nascido da sociedade, mas posto acima dela se distanciando cada vez mais, é o Estado (ENGELS, 2005, p.191).

Ainda ressaltando o parecer de Fernandes sobre Lenin e sua obra, dois pontos merecem ser destacados. O primeiro diz respeito ao mérito da sistematização elaborada por Lenin e sua perspicácia em atualizar os fundamentos de Marx e Engels à luz das exigências do século XX, mediante os novos desafios do imperialismo ${ }^{6}$. O segundo alude aos elementos que são basilares para um revolucionário do calibre de Lenin, que não está dedicado a um processo de sistematização de ideias com vistas a exercer a função de “cientista político" ou "teórico de gabinete” (p. 11), ao contrário, o que o move é a "ação revolucionária concreta" (idem), por isso toda atenção deveria estar voltada para o profundo entendimento do significado da conquista do poder pelo proletariado, da forma Estado daí resultante, do questionamento sobre "democracia de maioria" e, por fim, o inevitável definhamento do Estado diante do desenvolvimento socialista e a implantação de uma sociedade comunista. Porém, Lenin não guardava nenhuma ilusão: “[...] a substituição do Estado burguês pelo Estado proletário não é possível sem revolução violenta. A abolição do Estado proletário, isto é, a abolição de todo e qualquer Estado, só é possível pelo seu definhamento". (p.43).

No que tange a toda a polêmica em torno da "democracia da maioria" e a ditadura do proletariado, Lenin, amparado em Engels, refletirá: a democracia não é a subordinação de uma minoria à maioria, antes, a democracia é um Estado que admite a subordinação de uma minoria à maioria, que se dá pelo exercício da violência sistemática de uma determinada classe sobre a outra. Portanto, o que nos interessa é a supressão do Estado, que encarna toda forma de violência entre os homens, e concluirá: “[...] em nossa aspiração ao socialismo, temos a convicção de que ele tomará a forma de comunismo e que, em consequência, desaparecerá toda necessidade de recorrer à violência contra os homens, à submissão de um homem ao outro [...]. Os homens, com efeito, se habituarão a observar as condições elementares da vida social, sem constrangimento nem subordinação (LENIN, 2007, grifos no original. p. 118)".

Não será possível nesse curto espaço discorrer sobre o papel do conselho operário na concepção lenineana. Interessa, por ora, trazer a formulação de Lukács (2012) que o apresenta como sendo o "Estado como arma na luta de classes do proletariado" (p.80), indicando as implicações para o proletariado quando esta concisão não é apreendida e compreendida em todo o seu potencial e sua relação com a dita “democracia”. A argumentação é a seguinte: a concepção revolucionária do oportunismo, combatida veementemente pelos bolcheviques, entende que cabe ao proletariado lutar contra a dominação de classe da burguesia, empenhando-se na construção de uma sociedade sem classes, supondo-se contrário a qualquer forma de dominação de classe, inclusive a sua própria. Essa visão utópica revela “[...] uma capitulação ideológica diante da burguesia" (p. 81), dado que bloqueia, no real, a possibilidade concreta de dominação da classe trabalhadora, reforçada pela abstrata ideia de democracia como a prevalência dos interesses da maioria, desconsiderando por completo que essa é a forma mais avançada de dominação burguesa.

A resultante disso, conforme salienta o autor, é a crença em uma suposta igualdade de voz e direitos para cada cidadão, obliterando, justamente, a noção de que os homens "[...] não são indivíduos 
abstratos, cidadãos abstratos, átomos isolados de um todo estatal, mas são, sem exceção, homens concretos, que ocupam um lugar determinado na produção social e cujo ser social [...] é determinado por essa posição" (LUKÁCS, 2012, p.81). Evidente que essa lúcida ponderação não pode nos levar a interpretações rebaixadas, antidialéticas, assentadas no extremo oposto de que tanto faz a forma de Estado na luta do trabalhador contra a burguesia. Aqui é preciso recuperar Lenin em O Estado e a revolução, em sua magistral compreensão dialética: "Nós somos partidários da república democrática como sendo a melhor forma de governo para o proletariado sob o regime capitalista, mas andaríamos mal se esquecêssemos de que a escravidão assalariada é o quinhão do povo mesmo na república mais democrática" (2012 p.40).

Para finalizar, talvez a mais emblemática síntese sobre a atuação teórica e política de Lenin, no que se refere ao Estado, seja aquela proferida por Lukács (2012 p.85), em 1924, ao analisar o pensamento de Lenin: "O valor do Estado como arma para o proletariado depende daquilo que o proletariado será capaz de fazer com ele". A lição lapidar deixada pelo revolucionário Vladimir Ilich Ulyanov (Lenin) expressa, na contemporaneidade, um dos maiores desafios na luta pela superação do capital em um contexto no qual a velha quimera da conciliação de classes, acompanhada da tomada do Estado como um fim em si mesmo, grassa de forma expressiva em setores da esquerda no Brasil sob a justificativa da "governabilidade"7.

Eis então a validade de resgatarmos a crítica marxista absorvida por Lenin de que, dado o caráter de classe do Estado, da sua função de conservação da propriedade privada e de salvaguarda dos interesses dominantes, é urgente o contraponto à concepção liberal-burguesa do Estado como comunidade ilusória e à ineficácia das lutas políticas que, embrenhadas somente no seio deste, acabam por encobrir as lutas efetivas das diferentes classes.

\section{Referências:}

BORON, Atilio. Filosofia política marxista. São Paulo: Cortez; Buenos Aires: CLACSO, 2003.

BRAZ, Marcelo. Lutas de classes, luta revolucionária e partido em Lenin: significado e atualidade do "Que Fazer? ". In: Lenin: teoria e prática revolucionária. DEO, Anderson, MAZZEO; Antonio Carlos; DEL ROIO, Marcos (organizadores). Marília/SP: Oficina Universitária; São Paulo: Cultura Acadêmica, 2015. P. 57-82.

DEL ROIO, Marcos. Lenin e a transição socialista. Revista Lutas \& Resistências, Londrina, n.3, v.2, p. 67-82, $2^{\circ}$ sem. 2007, 67-82.

DEL ROIO, Marcos. Gramsci e Lenin. In: Gramsci e a emancipação do subalterno. São Paulo: Editora UNESP, 2018, p. 75-94.

DEO, Anderson, MAZZEO; Antonio Carlos; DEL ROIO, Marcos (organizadores). Lenin: teoria e prática revolucionária. Marília/SP: Oficina Universitária; São Paulo:Cultura Acadêmica, 2015.

ENGELS, Friedrich. A origem da família, da propriedade privada e do Estado. 17.ed. Rio de Janeiro: Bertrand Brasil, 2005.

FERNANDES, Florestan. Apresentação. In: LENIN, Vladmir Ilitch. O Estado e a Revolução: o que ensina o marxismo sobre o Estado e o papel do proletariado na revolução. São Paulo: Centauro, 2017, p.07-16. 
IASI, Mauro; FIGUEIREDO, Isabel M. e NEVES, Victor (Orgs). A estratégia democrático-popular: um inventário crítico. Editora: Lutas anticapital, 2019.

HELL, Victor. A idéia de cultura. São Paulo: Martins Fontes, 1989.

HOBBES, Thomas. O Leviatã. São Paulo: Martin Claret, 2004.

LENIN, Vladmir Ilitch. O Estado e a Revolução: o que ensina o marxismo sobre o Estado e o papel do proletariado na revolução. São Paulo: Centauro, 2017.

LENIN, Vladmir Ilitch. Sobre as Tarefas do Proletariado na Presente Revolução (Teses de Abril). Escrito em 4 e 5 (17 e 18) de Abril de 1917. Primeira Edição: Publicado em 7 de Abril de 1917 no jornal Pravda, n. ${ }^{\circ}$ 26. Fonte: Obras Escolhidas em Três Tomos, 1977, Edições Avante! - Lisboa, Edições Progresso - Moscou. Tradução: Edições "Avante!" com base nas Obras Completas de V. I. Lénine, 5. ${ }^{a}$ ed. em russo, t. 31 pp. 113-118. Disponível em: https://pcb.org.br/portal/docs/astesesdeabril.pdf. Acesso em 20/06/2020.

LENIN, Vladmir Ilitch. Imperialismo, fase superior do capitalismo. Lisboa: Edições Avante!, 1975.

LOCKE, John. Dois tratados sobre o governo. 2.ed. São Paulo: Martins Fontes, 2005.

LUKÁCS, György. Lenin: Um estudo sobre a unidade de seu pensamento. São Paulo, Boitempo, 2012.

MARX, Karl. Contribuição à crítica da Filosofia do Direito de Hegel. Manuscritos econômicofilosóficos. Lisboa: Edições 70, Tradução de 1975 por Artur Morão, 1993.

MARX, Karl. A questão judaica. Manuscritos econômico-filosóficos. Lisboa: Edições 70, Tradução de 1975 por Artur Morão, 1993.

MARX, Karl, ENGELS, Friedrich. Manifesto do Partido Comunista (1848). Porto alegre: L\&PM, 2001.

MARX, Karl, ENGELS, Friedrich. A ideologia alemã I e II. 3.ed. Lisboa: Editorial Presença; São Paulo: Martins Fontes, s/d.

NETTTO, José Paulo. Introdução ao estudo do método em Marx. São Paulo: Expressão popular, 2011.

ROUSSEAU, Jean-Jacques. Discurso sobre a origem e os fundamentos da desigualdade entre os homens. Brasília: Editora da UNB, 1985.

ROUSSEAU, Jean-Jacques. Do contrato social. Petrópolis: Vozes, 1995.

\section{Notas}

1 Doutorado em Educação pela Universidade Federal de Santa Catarina (2004). Professora Associada do quadro permanente da Universidade do Estado de Santa Catarina, UDESC, atuando no Centro de Ciências da Educação, no curso de Pedagogia e no curso de Mestrado e doutorado do Programa de Pós-graduação em Educação, na linha de pesquisa política educacional, formação e ensino. Integra o Núcleo de Estudos sobre as Transformações no Mundo do trabalho - TMT (http://dgp.cnpq.br/dgp/espelhogrupo/1617630968658640) e o Grupo de Pesquisas - Lutas Sociais, Trabalho e Educação ( LUTE) (http://dgp.cnpq.br/dgp/espelholinha/8112760204456378723158). Lattes: http://lattes.cnpq.br/0216250252557428; ORCID: http://orcid.org/0000-0001-8746-9001. Email: marileiamaria@hotmail.com.

2 Doutorado em Filosofia da Educação pela UNICAMP (2009). Professora do Departamento de Metodologia de Ensino do Centro de Ciências da Educação da Universidade Federal de Santa Catarina (MEN/CED/UFSC), e do Programa de PósGraduação em Educação (PPGE/UFSC). É líder do TMT/ Núcleo de Estudos sobre as Transformações no Mundo do Trabalho (UFSC/CNPq) - http://dgp.cnpq.br/dgp/espelhogrupo/1617630968658640; Integrante do Grupo de Estudos e Pesquisas Antonio Gramsci - http://dgp.cnpq.br/dgp/espelhogrupo/4739150674690618; ORCID: http://orcid.org/0000-0001-53131002; Lattes: http://lattes.cnpq.br/6655683758937444. Email: lumarcassa@gmail.com

3 Conforme informações extraídas da síntese proposta por Victor Hell (1989).

4 No Discurso sobre a origem e os fundamentos da desigualdade entre os homens, Rousseau (1985) afirma que o homem é naturalmente bom e ingênuo e que são os costumes que o corrompem, embora não destruam os princípios naturais relacionados à conservação da vida e do bem estar, à sensibilidade e à compaixão que lhe são inerentes. No estado natural, os homens não 
podem ser considerados nem bons nem maus, não têm vícios, nem virtudes, uma vez que eles não mantêm entre si nenhuma relação moral. Ao contrário de Hobbes, Rousseau considera que "o estado de natureza, sendo aquele em que o cuidado com nossa preservação é o menos prejudicial à de outrem, consequentemente seria o mais favorável à paz e o mais conveniente ao gênero humano" (p.73).

5 Por razões de espaço não serão aqui abordados todos os aspectos da conjuntura político-econômica desse período e todos os antecedentes que marcaram a constituição de Lenin como líder bolchevique e a sua responsabilidade pelo desfecho da Revolução Russa. Para um estudo potente sobre Lenin consultar LUKÁCS, György. Lenin: Um estudo sobre a unidade de seu pensamento. São Paulo, Boitempo, 2012.

6 Cf. LENINE, Vladimir I. Imperialismo, fase superior do capitalismo. Lisboa: Edições Avante!, 1975.

7 Para uma análise da esquerda no poder no Brasil, notadamente o PT, Cf. IASI, Mauro; FIGUEIREDO, Isabel M. e NEVES, Victor (org). A estratégia democrático-popular: um inventário crítico. Marília: Lutas anticapital, 2019.

Recebido em: 30.06 .2020 Aceito em: 25.08.2020 